\title{
The Scarecrow Christ: The Murder of Matthew Shepard and the Making of an American Culture Wars Martyr
}

\author{
Paul Middleton
}

On the night of Tuesday, 6 October 1998, Matthew Shepard, a gay twenty-one year old political science student at the University of Wyoming, met two other men, Aaron McKinney and Russell Henderson, in the Fireside bar in Laramie, Wyoming. After offering him a ride in their car, they robbed Shepard, drove him to the outskirts of town, and tied him to a fence. There, McKinney brutally beat him with a .357 Magnum around the head as Henderson watched. They left him, still tied to the fence, bleeding profusely in freezing temperatures. He was found by chance some eighteen hours later by a passing cyclist, who at first mistook him for a scarecrow. Shepard sustained massive injuries including a crushed skull, and was rushed to Poudre Valley Hospital in Fort Collins, Colorado. However, his injuries were too severe to treat, and he never regained consciousness. In the early hours of Monday, 12 October 1998, seven weeks short of his twenty-second birthday, Matthew Shepard died.

The brutal murder of Matthew Shepard was one of well over 1000 reported attacks on gay men that year, and one of around 30 murders. While each of the other murders went largely unreported, not only was Matthew Shepard's death announced by a Poudre Valley Hospital spokesman to a large crowd of journalists and television crews, by the time he died, his attack had been widely covered in the national press, and several vigils had taken place across the country attended by thousands and addressed by celebrities, including Ellen Degeneres and Kristen Johnston. America appeared to be in a state of shock, as hate crime against gay people entered public consciousness like never before. Within hours of Shepard's death, President Bill Clinton told reporters from the White House lawn, 'In our shock and grief one thing must remain clear: hate and prejudice are not American values'. ${ }^{1}$

While the speed and extent of the coverage was unusual for a gay hate crime, the content of that coverage was even more remarkable. Almost immediately, martyrdom tropes entered into public consciousness. On 19 October, just one week after Matthew's death, Time Magazine reported on the story: 'He wanted to find love. But as he lay near death, Matthew Shepard, through no fault of his own, had found martyrdom'. ${ }^{2}$ The following week, it was their front page story. Alongside the headline 'The War over Gays' was a picture of Shepard and a fence. The fence and the initial witness report that he thought the dying victim was a scarecrow resonated in the popular American religious imagination with the image of crucifixion. The New York Times and The Washington Post both commented on the 'incredible symbolism' or 'powerful Christ-like imagery' of the scene, ${ }^{3}$ which was also invoked by Rebecca Isaacs of the National Gay and Lesbian task force, ${ }^{4}$ and the Bishop of Los Angeles, who commented that Shepard had been 'beaten and left here, in the United States, in 
30-degree weather tied to a fence, his arms extended, all too reminiscent of a crucifixion. $^{5}$

Although the police originally suspected robbery to be the motivation for the crime, the murder was branded a hate crime in the earliest days. His sexuality was placed at the centre of the developing crucifixion narrative. Matt Shepard (as his parents and friends called him), a victim of a brutal murder in the American midWest, was transformed through what Loffreda calls 'a strange American transubstantiation' into Matthew Shepard, a national gay martyr. ${ }^{6}$ To coincide with the funeral, a Florida church held a 'Mass for a gay martyr', while Newsweek ran a story a few weeks later on 'The final days and nights of a gay martyr'. ${ }^{7}$ At the funeral, the Rev. Royce W. Brown brought the martyrological and Christological themes together:

There is an image seared upon my mind when I reflect upon Matt on that wooden crossrail fence. However, I have found a different image to replace that with and that is the image of another man, almost 2,000 years ago. ... When I concentrate on the Son of God being crucified, only then can I be released from the bitterness and anger I feel. ${ }^{8}$

In this essay, I examine the popular martyr-making process in respect of Matthew Shepard, arguing that both the making of the martyr and the reaction it provoked reflects American 'culture wars'. Martyrology is conflict literature. However, as I have argued before, the most significant conflict in a martyrdom story is not necessarily between the martyr and the agents of execution, but the story-tellers and their opponents. ${ }^{9}$ Yet, martyrological narratives are difficult to control, as I will demonstrate from the contested nature of Shepard's secular canonisation process. For at least some in the LGBT community, the dominant hagiography of Matthew Shepard, the gay martyr, is seen as unhelpful. Ironically, both LGBT activists and right-wing religious groups have in some ways sought to undermine Shepard's martyr status, by focusing on his life rather than his death. Nonetheless, I argue, such efforts continue to have limited effect because in martyrologies any interest in the lives of their heroes is incidental, merely setting the scene for a significant death.

\section{Canonisation}

Even granting a degree of elasticity to the title 'martyr', Shepard's death does not conform to traditional definitions of martyrdom, in which an individual is given an opportunity but refuses to recant of deeply held beliefs that leads to death. ${ }^{10}$ Yet, as we have noted, his status as a martyr was established within a week of his death. This raises the further question: who decides who is a martyr? While the Roman Catholic Church has an official 'canonisation' process, popular acclamation often bypasses official recognition. 
As Hoffman has demonstrated, Americans have a particularly developed history of popular martyr-making. ${ }^{11}$ He points to abolitionist agitator John Brown, Abraham Lincoln, and, of course, Martin Luther King Jr. Even beyond the shores of America, the affirmation that Martin Luther King was in some way a 'martyr' would meet little resistance. ${ }^{12}$ Yet King or the others cannot be said to have died in odium fidei, a crucial step in the Roman Catholic canonization process; their deaths were clearly 'political' rather than 'religious'. ${ }^{13}$ Perhaps most importantly, they, like Shepherd, did not deliberately die for their cause. Jensen, Burkenholder, and Hammerback dub them 'accidental martyrs', or 'rhetorical martyrs' in contrast to what they call 'real martyrs'. ${ }^{14}$ However, this is to misunderstand the nature of martyrdom and martyrology. All martyrdom literature is rhetorical; stories about the deaths of martyrs are written and recounted for a purpose, for ultimately no martyr can control the account of his or her death. Martyrs need a witness in the form of a narrator.

Martyrologies create or reinforce identity boundaries, as narrators presents martyrs as exemplars of their own group with mimetic potential. In the case of early Christian martyrdom, readers may well have had to ready themselves to follow this example by confessing before a governor and face execution. At the very least, the community would identify with the martyr, and recognise their own values reflected in the hero. But martyr literature does more than highlight heroes; it creates antiheroes or villains. The enemy - representatives of demonic forces, or the Beast of Revelation who demands the martyr recant - threatens the world view, values, or identity of the martyr's community.

The dramatic conflict in a martyrology reflects a social, or indeed cosmic battle in the world of the narrator and hearers or readers. It is the construction of martyr narratives, or indeed resistance to them, that reveals the true conflict story, whether between Christians and Romans, Donatists and Catholics, Catholics and Protestants, or the West and groups labelled 'terrorists'. Martyrologies are neither ideologically neutral nor objective, but are bound up with questions of identity. They reinforce a group's particular view of the world-whether religious, political, or national-which is why they can be so potent and controversial. ${ }^{15}$ Martyrology presents a representative hero who not only stands for, but dies for the community at the hands of an enemy which threatens it. The sharp boundary between the threatened insiders and the persecuting outsiders reinforces group identity in a dangerous and dualistic world.

\section{The Martyrological Battle: American 'Culture Wars'}

Homosexuality, along with abortion, has long been the touch stone issue in America's so-called 'culture wars' that divides the Religious Right from secularizing liberals. Gay Rights, Gays in the Military, and most recently, Gay Marriage have energized both sides of this battle. ${ }^{16}$ From the Stonewall riots of 1969 and the 
emergence of radical movements, such as the Gay Liberation Front, the cause of Gay Rights progressed through the next decade: in 1973, the American Psychiatric Associate removed homosexuality from their list of psychiatric disorders; openly gay politicians, such as Harvey Milk were elected; and the first Gay March (the precursor to Pride) was held in Washington in 1979. However, these steps forward provoked a furious backlash from the Christian Right, such as Jerry Falwell and his 'Moral Majority' movement, who declared it was time 'to stop gays dead in their perverted tracks'. ${ }^{17}$

The AIDS crisis of the 1980s did indeed halt the progress of the liberation movement, widely welcomed as 'God's judgement', rhetoric only mildly toned down when the HIV virus began to affect groups other than gay men. However, the AIDS crisis invigorated fresh activism, spawning radical movements, such as ACT UP (AIDS Coalition to Unleash Power) and Queer Nation to campaign for better drug therapies as well as wider social reform. By the mid-1990s, in the face of violence against Lesbian and Gay communities, pressure was building for sexual orientation to be included in state hate, or anti-bias, laws, although it would take until 2009 to come to fruition, when President Barak Obama signed the Matthew Shepard and James Byrd hate crime legislation.

However, the Religious Right engaged in counter-offensive manoeuvres, establishing anti-gay marriage laws in many states in response to Vermont recognising same-sex unions. They claimed an initiative by Bill Clinton to teach school children about the dangers of intolerance was effectively declaring 'war on Christian parents and children'. ${ }^{18}$ Moreover, in response to the increasing number of celebrities 'coming out', the 'ex-gay' ministries group, Exodus International, joined with Focus on the Family, raising funds to run a full page advertisement in the New York Times to declare a 'National Coming Out of Homosexuality Day' to coincide with 'National Coming Out Day'. In a twist of fate, these were scheduled for 11 October 1998 to mark Gay Awareness Week beginning the following day; the day on which Matthew Shepard died.

Matthew Shepard's death, or perhaps more accurately, the reporting of Shepard's death, shone a spotlight on America's relationship with its Lesbian and Gay citizens. The particularly brutal nature of the attack, the length of time Shepard spent tied to the fence, and then in a coma, at precisely the time at which the opposing sides lined up with their 'Coming Out' events both gave time for the media to mobilise, and shape the narrative of the murder into one of discrimination and hate. Indeed, the murder gave 'liberals' ammunition against their conservative opponents. Jonathan Alter accused Republicans of portraying homosexuals in a way that directly led to the attack on Shepard. In the same way as 'white racists created a climate for lynching blacks, so the constant degrading of homosexuals is exacting a toll in blood' ${ }^{19}$ Washington Post columnist, Richard Cohen, held Trent Lott, the Republican Senate Majority Leader responsible for creating the conditions that led to the murder: 'Anti-gay politicians have given voice to some of the ugliest sentiments in American society-legitimizing the sort of hate that left Matthew Shepard tied to a 
fence, lynched on account of being gay.' ${ }^{20}$

The Religious as well as the political Right were also implicated in the attack. The ex-gay movement's high profile protest as Matthew Shepard lay in a coma was damaging, and their advertising campaign was suspended. ${ }^{21}$ The 'non-violent world of "love the sinner, hate the $\sin ^{\prime \prime \prime 22}$ was under so much pressure that the editors of Christianity Today felt the need to intervene and work hard to deny the link between Christian faith and the murder:

Spokespersons for gay liberation were quick to accuse the so-called Religious Right of creating the hostile environment in which hate crimes against gays flourish. Their surreal thesis indicted anyone who publicly condemns homosexuality as playing a part in Matthew Shepherd's death. Gay activists cited as Exhibit A the recent 'truth in love' advertising campaign, which claimed that a change of sexual orientation is possible and produced ex-gays to prove it. ${ }^{23}$

While robust in its denial of the link between condemning homosexuality and the attack, the sub-headline acknowledged some discomfort at Christian complicity in the murder: 'Human nature being what it is, we can too easily cross the line between hating the sin and hating the sinner' ${ }^{24}$ This line was indeed crossed, most obviously by the high profile presence of the then little-known Fred Phelps and his small congregation from the Westboro Baptist Church. First, they picketed Shepard's funeral, then the trials of Henderson and McKinney, with placards, such as: 'No Fags in Heaven'; 'No Tears for Queers'; 'Fags Die, God Laughs', all gathered together under the Church's website: godhatesfags.com, which included a photograph of Matthew Shepard in the midst of the flames of hell.

Interestingly, the Christianity Today editorial portrays this group of Christians as the mirror image of the gay activists, who like Phelps, 'politicized' Matthew's murder, 'despite his father's plea not to "use Matt as part of an agenda."' 25 However unconvincing, the conservative Christian editors attempted to 'scapegoat' a similar expression of Christianity as the 'other', ${ }^{26}$ and position themselves in the moderate centre between extreme Christian and extreme pro-gay positions. Nonetheless, it is hard to escape Casey's conclusion that for those on the American Right 'animus towards gay men is pervasive, public, and well within the boundaries of...family values. ${ }^{27}$

This culture war can be illustrated from the other side by another unlikely 'accidental martyr'. On 20 April 1999, less than six months after the murder of Matthew Shepard, two students went on a shooting spree at Columbine High School, Littleton, Colorado, killing thirteen fellow students, including Cassie Bernall. In a now famous exchange, one of the gunmen found Cassie under a desk and asked if she believed in God. When she said, 'yes', he shot her dead. Cassie was proclaimed a martyr in newspapers and websites. ${ }^{28}$

A few weeks after the massacre, doubt was cast on the veracity of this account. 
Though the story had originally come from one survivor, two other accounts soon emerged. One has Cassie saying, 'Dear God. Dear God. Why is this happening? I just want to go home.' The gunman then slammed his hand on the table, yelling 'peekaboo' and shot her without any further words being exchanged. The third version has another student, Valeen Schnurr, rather than Cassie, interacting with the gunman. Though she had told him she believed in God, he walked away. The investigators believe this latter account to be the most likely 'historical reconstruction'. However, the first, with Cassie saying 'yes' remains the dominant narrative for evangelical Christians.

Cassie's mother, Misty Bernall, effectively 'canonised' this account, in her book She Said Yes: The Unlikely Martyrdom of Cassie Bernall. There is a strong focus on Cassie's life. It is a story of a troubled teenager struggling with drugs and alcohol until she was dramatically converted to Christianity. Her framing of the story as a

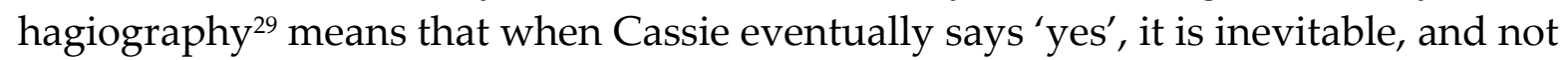
that 'unlikely'. Many young people were inspired by Cassie's example, and there was a surge in membership of religious youth groups, neatly illustrating the powerful appeal of martyrs. However, the counter-narratives persist, promoted generally by secularist websites, reflecting the 'culture wars' between Christianity and Secularism..$^{30}$ Each side has its version of Cassie's 'martyrdom' reinforcing their view of the world.

The Christian Right have continued to invoke persecution and martyrdom narratives for less dramatic events, such as losing votes on same-sex marriage. However, these political martyrologies found a tangible focus in Kim Davis, a marriage registrar who was jailed for refusing to conform to a court order to issue licenses to a gay couple. The American Conservative magazine hailed her as a 'CultureWar Martyr', ${ }^{31}$ while The New York Post went further:

She's gone from being an obscure county clerk to a Christian martyr. The jailing of Kim Davis, the Kentucky official who just said no, is a case of religious persecution that should strike fear in the hearts of all Americans - gay, straight or anything else. ${ }^{32}$

Clearly, with its heroes and villains, the martyrdom of Kim Davis is as divisive as any martyrology - even though Davis is still very much alive. The judicial penalty enabled religious leaders and the media to draw on early Christian martyr narratives of persecution. Naturally, many have resisted the canonisation of Kim Davis, but David Uberti's complaint that 'The media has made Kim Davis a conservative martyr, missing the bigger picture' misses the point. ${ }^{33}$ As I have been arguing, martyr narratives reflects the wider conflict in which the narrator is engaged, and so Davis' story, like Bernall's and Shepard's functions precisely as a martyrology should.

The stories of Cassie Bernall and Kim Davis function as an interesting counterpoint to the martyrology of Matthew Shepard. Whereas in Misty Bernall's book, the details of her daughter's life reinforce the martyr narrative, as we will see, 
Matthew's mother, Judy Shepard, was concerned that her son's life was being obscured by his martyrdom. Whereas to create a saint, a good life is required, to make a martyr, all that is really needed is a death. With Cassie Bernall, details of her life were needed to establish a Christian identity; in the case of Matthew Shepard that he was gay is the only detail necessary for the construction of his martyrdom. We now turn to the way in which Matthew Shepard so quickly became an important and influential gay martyr.

\section{'The Good Shepard': The Making of a Martyr}

For a martyr narrative to work, it must emphasise community boundaries and create an outside, 'evil other'. Martyr literature forces the reader to choose sides. ${ }^{34}$ It is my contention that the Matthew Shepard martyrology was so powerful because it created multiple sites of identity, both positively and negatively. We have already seen how the editors of Christianity Today struggled to situate themselves in the narrative, clearly uncomfortable with their obvious identification with the 'outsider'. In the same way, liberal America, which could not claim the status of an 'insider' (at least initially), saw its role in some way as 'witnesses' - to use the original meaning of martus - or supporters of Matthew's 'cause'. As a country at best ambivalent on gay rights, Shepard's death, 'shook the nation', ${ }^{35}$ as 'for the first time, in cities across the United States and Canada, straight people have marched by the thousands to protest anti-gay violence.' ${ }^{36}$

We have already noted the fact the framing of the assault as a homophobic attack along with the 'crucifixion' imagery of the scarecrow were the most significant hooks on which the media ran their stories. In fact, Shepard was tied seated on the ground with his hands behind his back, rather than in crucifixion position. Although this was widely reported, it did not detract from the crucifixion imagery, probably because the iconic potential of the picture of the empty fence. In their analysis of the media portrayal of the attack and its aftermath, Ott and Aoki suggest this local story found its way into the national press because the mixture of a gay crime, scarecrow/crucifix imagery, and sheer savagery of the attack gave the story 'melodramatic potential'. ${ }^{37}$ Moreover, the length of time between attack and death was also a significant factor: 'That Shepard lay comatose in a hospital for several days while people around the country prayed and stood vigil for him, functioned to heighten the public's investment in the story' ${ }^{38}$

A further element in the story's 'melodramatic appeal' was the physical aspects of Shepard. He was young, white, middle-class, small at $158 \mathrm{~cm}$ and just 105 pounds in weight. Although the American public knew Matthew Shepard was gay, the 'Shepard iconography' was not threatening. Reporting of the initial attack emphasized Shepard's vulnerability, using words and phrases like trusting, softspoken, polite, sweet, boyish, cherubic face, shy, sensitive, like a child, meek, well groomed. The policewoman who attended the scene said he looked more like a boy than a man, which created an image of a young child-saint, and crucially, de- 
sexualised, raising the uncomfortable question: 'Would Shepard have received the attention he did had his body not so easily been coded as unthreatening.'39

So while America's gay communities recognised the familiar hate crime that murdered Shepard as a real, experienced, every-day reality, ${ }^{40}$ as Ott and $\mathrm{Aoki}^{41}$ note, for the media and mainstream America, the focus on Shepard's body made him, rather than the hate crime, the central focus of a human interest story. ${ }^{42}$ Comparing the coverage of the Shepard murder with the relative lack of media interest in five black victims of an anti-gay Washington serial killer, or a transgender 16-year-old in Colorado, they conclude, 'an anti-gay murder is tragic so long as the victim is not too gay, which is to say, too different.' ${ }^{43}$ As journalist Melanie Thernstrom puts it:

Parents throughout the country felt that Matthew could have been their son, an idea many had never contemplated before about a gay person. In part, this may have been a result of the fact that while he was described as gay, the press - in unwitting collusion with homophobia-did not portray Matthew as a sexual adult. He was depicted as having parents, rather than partners-loving, affluent, married American parents... He had a fragile, childlike look - a look of pale purity, the translucent beauty favored in religious art. $^{44}$

To put it another way, the ability of general America to identify with Shepard, together with the Christological imagery drawn from the well of American religiosity, exacerbated by the presence of Fred Phelps, ${ }^{45}$ were the currents that carried the story well beyond Laramie.

The alter Christi interpretation persisted in artistic and musical representations of the martyrdom. Phil Hall's musical, Matthew Passion (2007) intersperses the story of Shepard and Christ, with God welcoming Matthew at the end. In the 2001 MTV documentary, Anatomy of a Hate Crime: The Matthew Shepard Story, Matthew is, despite the actual murder scene, depicted tied to the fence with arms outstretched, as in crucifixion. Yet while Judy Shepard thought the comparisons with Christ were both 'questionable and inappropriate', ${ }^{46}$ even she acknowledged the representative nature of her son, dedicating her book 'to all the "Matts" out there'. Moreover, not only was the link made explicit in the funeral eulogy, but also in other important ways. For example, aside from inspiring the eventually successful hate crimes legislation in his name, he is credited with post-mortem or intercessory agency generally associated with saints.

First, although there was never any hope that Shepard would recover, he relieves his parents of having to switch off his life support. In a statement, Judy and Dennis attributed the decision to die to Matthew (cf. In 10.18): 'Like a good son, he was caring to the end and removed guilt or stress from the family' ${ }^{47}$ They also attributed the speed of the investigation - both killers were arrested within a couple of days - to an unspecified supernatural agent: 'it seemed to all of us that somebody, something, or some power stepped in to, as much as possible, set things right' ${ }^{\prime}{ }^{8}$ 
More dramatically, Matthew Shepard 'intervenes' in the sentencing of Aaron McKinney, to 'save' him from the death penalty. It had become clear that McKinney had carried out the beating that killed Shepard, while his accomplice, Russell Henderson watched, although Henderson had tied Matthew to the fence. Henderson had already plead guilty to kidnap and murder, and his plea bargain of two life sentences rather than face the death penalty had been accepted. McKinney, however, entered a plea of not guilty and forced a trial. Having been found guilty, he faced the death penalty. However, although in favour of capital punishment, Dennis Shepard addressed the court:

Matt officially died at 12.53am on Monday, October 12, 1998, in a hospital in Fort Collins Colorado. He actually died on the outskirts of Laramie, tied to a fence that Wednesday before, when you beat him. You, Mr. McKinney, with your friend Mr. Henderson, killed my son. ... You left him out there by himself, but he wasn't alone ... He had God. ... Matt became a symbol - some say a martyr, putting a boy-next door face on hate crimes. That's fine with me. Matt would be thrilled if his death would help others ... My son has become a symbol-a symbol against hate and people like you; a symbol for encouraging respect for individuality; for appreciating that someone is different for tolerance. ... I would like nothing better than to see you die, Mr. McKinney. However, this is the time to begin the healing process. To show mercy to someone who refused to show any mercy ... I'm going to grant you life, as hard as that is for me to do, because of Matthew ... You robbed me of something very precious, and I will never forgive you for that. Mr. McKinney, I give you life in the memory of one who no longer lives. May you have a long life, and may you thank Matthew every day for it. ${ }^{49}$

In his extraordinary and moving court statement, Dennis Shepard accepts his son as a martyr, and although he highlights the violence of the attack, also paints a picture of a peaceful death in which Matthew dies surrounded by nature, listing the sky, stars, moon, and then the daylight, wind, and finally, God. In doing so, he reinterprets a violent death into a religious death in which God was present, echoing the martyrdom of Stephen and perhaps Luke's Jesus (cf. Acts 7.54-59; Lk. 23.46). Moreover, while he would happily see his son's murderer die, it is in Matt's name that Dennis Shepard spares Aaron McKinney's life. Saint Matthew, the martyr, grants life to the sinner deserving of death (cf. Lk 23.24; Acts 7.60).

However, both parents were from the outset anxious by the burden of sainthood placed on Matthew. They wanted to counter or at least augment, the 'gay saint' narrative with details of his life, the 'real' Matt, which, as Thernstrom observes, was obscured in the martyr-making process: 'The mythologizing of Matthew - his overnight transformation into a national and international symbol - has left him oddly faceless. No one has seemed interested in publishing the details of his life-as 
if they would detract from his martyrdom. ${ }^{50}$

Indeed, something of his mother's frustration comes through in the introduction to her book, published more than ten years later:

You knew him as Matthew. To us he was Matt. I have tried to reconcile the two within these pages. It would be unfair to Matt if only Matthew's story was told. Matt was so much more than 'Matthew Shepard, the gay twentyone-year-old University of Wyoming college student.' He had a life before the night he was tied to that fence. ${ }^{51}$

Judy Shepard's book attempts to reconcile Matt her son with Matthew the martyr, insisting that the former is part of the 'meaning' of the latter. In the months after the murder, her concern was to protect the memory of Matt, whom she feared could not live up to the mythological figure into which he was being transformed. She told Thernstrom: 'He wasn't a saint. He was just a young man in search of himself.' She is disturbed by comparisons between Matthew and Jesus. 'You must understand, it's like putting him on a pedestal that just won't work. I'm concerned that if people find out that it's not true, they'll be disappointed or angry or hate him. ${ }^{\prime 52}$

However, in important respects, 'Matt' and 'Matthew' are two distinct entities, as is the case for all martyrs. While Shepard was involved in gay rights activism in his local university group, he never intended to die for the cause. However, narratives about his death have created Matthew Shepard, the martyr. His depression, the details of his life, his HIV positive status are simply not important in these narratives. Contrary to his mother's fears, the fact that Matthew was not a saint makes no difference to the function of his story. Rather the fact he was gay and murdered and that his death has provoked and inspired change makes him a gay martyr and a gay Christ figure. Matthew's death has become a death for others. Nonetheless, martyrs are controversial figures whose legacy divides. As with the Cassie Bernall martyrology, opponents in the culture wars have challenged the dominant narrative. However, unlike the Columbine martyr, some opposition has come from 'insiders' in the form of LGBT activists.

\section{'Demythologising Matt'}

The dominant martyr narrative for Matthew Shepard was challenging to the Religious Right. Holding 'Coming Out of Homosexuality Day' as the national media focused on the trauma unit in Poudre Valley was deeply damaging. Republican leaders were accused of contributing directly to the climate of intolerance and hate that led to attacks on gay people, including Shepard. Opposition to gay rights and, in particular, hate laws were unpopular, and threatened to undermine the carefully crafted narrative that homosexuals constituted the threat rather than the potential victims. Therefore, the main tactic adopted by the 'mainstream Religious Right' both at the time and in subsequent opposition to all proposed hate crime legislation has 
been to acknowledge the severity of the crime, but to insist robbery rather than homophobia was the motive. Bill Clinton's hate crimes legislation failed to pass through Senate, and stalled under George W. Bush. Similarly, speaking in opposition to the successful Matthew Shepard/James Byrd Jr Bill in 2009, Republican Senator, Virginia Foxx, noted the bill was named for Matthew Sheppard, and thus

is named after a very unfortunate incident where a young man was killed, but we know that young man was killed in the commitment of a robbery. It wasn't because he was gay. The hate crimes bill was named for him, but it's really a hoax that continues to be used as an excuse for passing these [hate crime] bills. ${ }^{53}$

Although Foxx later apologized for her use of the word 'hoax', her objection was essentially aimed at the main martyrological narrative of Matthew Shepard. She argued Shepard was not murdered because he was gay. Indeed, so far as Foxx is concerned, no one is. Instead, 'Matthew the martyr' is a 'hoax' to advance the 'homosexual agenda' to push through anti-hate laws, which would signal a capitulation to the Gay Lobby's demand for acceptance. For, as Eve Segwick, astutely observes, 'to specify a condemnation of individual violence against persons perceived as gay would violate the state's condemnation of homosexuality. ${ }^{54}$ Or to put in another way, 'to protect queers from the violence that faces them would endanger the patterns of allowed prejudice that, by most accounts, causes that violence. ${ }^{55}$

An early manifestation of these concerns came at the trial of Aaron McKinney. Jury selection began on the first anniversary of Shepard's death, and the martyrology was now fully developed. To stand any chance of saving their client's life, let alone achieve a not guilty verdict, McKinney's defence team had to 'attack the myth of St. Matthew'. ${ }^{56}$ Their tactic was to deploy the so-called 'gay panic defence', ${ }^{57}$ invoking the rhetoric of the Religious Right, that homosexuals were not victims but predators. The defence team claimed McKinney's intent was robbery, but he turned violent only after Shepard made sexual advances towards him, partly as a result of abuse McKinney had suffered as a child. ${ }^{58}$ McKinney's defence attacked the martyr narrative, and attempted to portray Matthew not as victim but aggressor. The irony of attempting to introduce sexual orientation into hate crimes law in a context in which the law potentially mitigates violence perpetrated against gay men has been noted ${ }^{59}$ Nonetheless, this strategy was dismissed by the judge.

Several other challenges to the martyr-Matthew narrative have been offered in the name of 'objective journalism' ${ }^{60}$ One of the earliest was a thoughtful but provocative piece on the nature of masculinity by JoAnn Wypijewski in Harper Magazine (1999). Written after Henderson's sentencing but before McKinney's trial, Wypijewski focussed on the two killers, arguing Henderson in particular was a victim of 'wussitude' or 'compulsory heterosexuality'. Perhaps more significantly, anticipating some LGBT concerns with the developing martyrology, Wypijewski observed a move to 'demonise' the killers as a means of divesting responsibility from 
the Nation's structural homophobia. There was a need 'to caricature McKinney as a devil-man, because to think of him as Laramie's, or anyone's child sits harder on the conscience.' ${ }^{61}$ Others argue the portrayal of Henderson and McKinney as 'White Trash' - a racial grouping distinct from 'White American', and certainly below Shepard's 'white middle-class' status - was a means of 'cleansing' society from all responsibility for the crime. ${ }^{62}$ So while Matthew Shepard plays a representative role for all gay people who are potential victims of violence, 'McKinney and Henderson stand [only] for themselves.' ${ }^{63}$

Two of the more sensational anti-martyr narratives came in the form of Elizabeth Vargas' ABC 20/20 documentary from 2004, ${ }^{64}$ and Stephen Jimenez's book, The Book of Matt (2013), which promised Hidden Truths about the Murder of Matthew Shepard. Both argued the attack was not a hate crime, but a drug-fueled altercation between those already acquainted, both suggesting Shepard and McKinney had been involved in a sexual relationship. The thesis of the 20/20 report was 'queers fabricated the defendants' homophobia'. ${ }^{65}$ While the allegation Shepard knew his assailants has been denied, all other so-called 'new facts' claimed by Vargas and Jimenez - Shepard's depression, assault and rape in Morocco, his HIV status, and drug use-were all well known. ${ }^{66}$ In response to criticism, Jeffrey Schneider, VP Media Relations at ABC defended the 20/20 broadcast: 'Our report was about the myths versus the facts of the Matthew Shepard case. Some of the myths lead to important discussions and changes in attitudes, but it is our job to look at the facts. ${ }^{67}$

Schneider, of course, suffers from a journalistic over-confidence in separating 'fact' from 'myth', used presumably and problematically to mean something that is untrue. Nonetheless, he is correct that 'myths' (used in the sense of narrative) have tangible consequences. Both versions clashed in the 2009 Hate Crimes debate. The bill bore Matthew Shepard's name, while the equally 'mythical' 20/20 report was cited as evidence in Virginia Foxx's opposition.

Nonetheless, resistance to the dominant martyr narrative has also come, perhaps surprisingly, from some LGBT activists, or those sympathetic to the advancement of LGBT rights. ${ }^{68}$ Ott and Aoki, for example, argue the media's framing of the attack worked 'rhetorically and ideologically to relieve the public of its social complicity and culpability; [and] to reaffirm a dominant set of discourses that socially stigmatizes ... GLBT ... persons' ${ }^{69}$ This works in two ways already mentioned. First, by scapegoating the killers, the media were both 'expunging the evil within, and restoring the social order.' ${ }^{70}$ Second, and more significant, is the desexualization of the martyr. The dominant image of Shepard was as an innocent child rather than a mature gay man. ${ }^{71}$ The gay-martyr began an uneasy transformation into an American 'everyman', who 'could have been the college-aged son of any stereotypical middle-class American family.' ${ }^{72}$

Importantly, transforming Shepard from Gay martyr to American martyr creates a different set of insiders and outsiders. No longer is the drama a clash between LGBT people and the Religious Right, along with mainstream society that sanctions the attitudes that nurture the hate that creates martyrs. Rather, when a de- 
sexualized middle-class white martyr is the hero, the 'other' includes not only 'white trash outlaws', but also sexually active gay men, especially black gay men, and transgressive transgender persons, who, because they do not conform to the image of Matthew the martyr, when they are subjected to violence, are somehow 'asking for $i^{\prime}$ '. In other words, if liberal America become the insiders, then some less publicly presentable gays are pushed out.

Nonetheless, this point can be overstated. That Matthew Shepard is expected to represent every gay, lesbian, and transgender person of every race and social class probably rests too great a burden on a single martyr, no matter how iconic the story. Part of the problem is embedded in the New York Times editorial at the time: 'For homosexuals, the key to winning acceptance and respect has been to make themselves familiar, visible and known. Yet in almost 30 years of struggle, the modern gay rights movement lacked a recognizable public face. Now, in a victim, it has been given one. ${ }^{73}$ Initially this victim status was politically useful, especially as it was reported as a civil rights issue. However, as several commentators have noted, such an iconic victim distracts from the 'hard, slow work for local justice. ${ }^{74}$ Gay rights activist, John Stoltenberg, argues that the martyr status of Shepard ignores the tragedies of his life prior to his murder. It is knowing his real lived experiences that will instead help 'young men in our community who are sold for sex, ravaged by drugs, and generally exploited. ${ }^{75}$ However, as Stoltenberg appears to acknowledge if he wants a figure to mirror the lived experiences of the gay community as they really are, then Matthew the martyr cannot do that, for that is not what martyrs do. While there have been many attempts to do so, for both positive and negative reasons - to promote or advocate gay rights, to demonstrate the real life struggles of a young American man, or to tarnish the reputation of a figure problematic to a Christian Right cause - martyrs cannot be controlled. Popular acclamation and meaningmaking operate beyond ecclesiastical, social, community or family control. The significance of a martyr is the story of how they died, not how they lived.

\section{Conclusion}

Matthew Shepard's brutal murder in 1998 shocked America, and the story of his death became a gay martyrology. Although only one of hundreds of incidences of violence against gay men in America, a constellation of factors - his looks, the manner of his death, the fence iconography, his remaining alive in a coma for several days, and the reporting that emphasised child-like innocence-transformed Matthew Shepard, an ordinary young American man, into a martyr, even undergoing 'resurrection as patron saint of hate-crime legislation. ${ }^{76}$ Like all martyr stories, accounts of Shepard's martyrdom are divisive, forcing those exposed to the narrative to choose sides in the culture wars that dominate American political and cultural life. Matthew Shepard's martyrdom, like Cassie Bernall's, divides the audience into heroes and villains. The power of martyrdom in the American imagination is demonstrated by the Religious Right, those cast as the villains by the Shepard 
martyrology, now claiming martyr status for themselves in the face of a 'liberal enemy' forcing gay marriage upon them after the Supreme Court struck down the ban on same-sex marriage in June 2015.

While some LGBT advocates have expressed frustration that Matthew Shepard's martyrdom cannot fulfil all they might wish it to, the martyrology has been and continues to be effective. Others complain the 'real Matt' has been lost in the battle for the advancement of gay rights; his life has been obscured by his death. However, as we have seen, it is difficult to control the meaning of martyrdom. For better or for worse, the reason martyrs are remembered is not because of the way in which they lived their life; the significance, power, and legacy of a martyr lies in the, albeit contested, meaning attached to their death.

\section{Endnotes:}

1. Associated Press Archive: https://www.youtube.com/watch?v=0qm8D-ANXg8

2. Howard Chua-Eoan, 'That's not a Scarecrow: A brutal assault in Wyoming and a rise in gay bashing fuel the debate over sexual orientation.' Time Magazine, 19 October 1998, p.72.

3. 'Gay Man Dies from Attack, Fanning Outrage and Debate.' The New York Times, 13 October 1998; 'Hundreds Gather to Remember Slain Man as "Light to the World."' The Washington Post, 17 October 1998.

4. 'People have likened it to a scarecrow. But it sounded more like a crucifixion.' In New York Times article above n.2.

5. Quoted in 'Religious Leaders Decry Wyoming Man's Slaying.' Los Angeles Times, 15 October 1998.

6. Loffreda, Losing Matt Shepard: Life and Politics in the Aftermath of an Anti-Gay Murder, p. ix-x.

7. Mark Miller, 'The Final Days and Nights of a Gay Martyr', Newsweek 21 December 1998, p.30.

8. Shepard, The Meaning of Matthew: My Son's Murder in Laramie, and a World Transformed, p. 185.

9. Middleton, 'What is Martyrdom?'

10. See van Henten and Avemarie, Martyrdom and Noble Death: Selected Texts from Graeco-Roman, Jewish and Christian Antiquity, p. 3.

11. Hoffman, "'Last Night, I Prayed to Matthew": Matthew Shepard, Homosexuality, and Popular Martyrdom in Contemporary America', p. 12324.

12. He is numbered among the 'Ten Modern Martyrs' installation over the door of Westminster Cathedral.

13. That Martin Luther King was a clergyman has helped efforts to frame his political beliefs, and therefore his death, in terms of religious martyrdom. The same is true of Dietrich Bonhoeffer; see Middleton, Martyrdom: A Guide for the 
Perplexed, p. 18-20.

14. Jensen, Burkenholder, and Hammerback, 'Martyrs for a Just Cause: The Eulogies of Cesar Chavez'.

15. Middleton, Radical Martyrdom and Cosmic Conflict in Early Christianity, p. 14; Middleton, 'What is Martyrdom?'.

16. See Chapman, Encyclopedia of the Culture Wars: Issues, Viewpoints, and Voices.

17. Quoted in Hoffman, "'Last Night, I Prayed to Matthew": Matthew Shepard, Homosexuality, and Popular Martyrdom in Contemporary America', p. 126.

18. Durham, The Christian Right, the Far Right and the Boundaries of American Conservatism, p. 51.

19. Jonathan Alter, 'Trickle-Down Hate.' Newsweek, 26 October 1998.

20. Richard Cohen, 'Legitimizing Hate.' Washington Post. 15 October 1998.

21. For a good account of the effect on the ex-gay movement, see Thorn, 'Confess the Gay Away? Media, Religion, and the Political Economy of Ex Gay Therapy', p. 175 - 182. Besen (Anything but Straight: Unmasking the Scandals and Lies behind the Ex-Gay Myth, p. 214) overstates the situation in saying that that 'Overnight, the right wing went from victor to vanquished in the culture wars. The success of their ex-gay campaign essentially evaporated into this air.' The campaign restarted less than twelve months later.

22. Wilcox, 'Murderers and Martyrs: Violence, Discourse, and the (Re)Construction of Meaning', p. 170.

23. 'Editorial: Who Killed Matthew Shepard?' Christianity Today, 7 December 1998.

24. Ibid.

25. Ibid.

26. See Wilcox, 'Murderers and Martyrs: Violence, Discourse, and the (Re)Construction of Meaning', p. 171.

27. Charles, 'Panic in the Project: Critical Queer Studies and the Matthew Shepard Murder', p. 244.

28. See Castelli, Martyrdom and Memory. Early Christian Culture Making, p. 172-96.

29. Castelli, Martyrdom and Memory. Early Christian Culture Making, p. 177.

30. Cullen, 'Who said Yes?'; Castelli, Martyrdom and Memory. Early Christian Culture Making, p. 184-87.

31. Dreher, 'Kim Davis: Political Prisoner? Culture-War-Martyr?'

32. Dreher, 'Kim Davis: Political Prisoner? Culture-War-Martyr?' One British newspaper, The Independent, was slightly less sympathetic with its headline: 'The US has a new anti-gay marriage martyr - a four-times wed county clerk' (5 September 2015).

33. Uberti's, 'The Media has made Kim Davis a Conservative Martyr, Missing the Bigger Picture.'

34. Cobb, 'The Media has made Kim Davis a Conservative Martyr, Missing the Bigger Picture', p. 6-11

35. 'The Good Shepard: Young man's death Shakes the Nation', The Advocate 10 November, 1993, p. 13. 
36. Justin Gillis and Patrice Gaines, 'Pattern of Hate Emerges on a Fence in Laramie.' Washington Post 18 October 1998.

37. Ott and Aoki, 'The Politics of Negotiating Public Tragedy: Media Framing of the Matthew Shepard Murder', p. 487.

38. Ibid: 490 .

39. Ibid: 495.

40. See Dunn, 'Remembering Matthew Shepard: Violence, Identity and Queer Counterpublic Memories', p. 621-22.

41. Ott and Aoki ' $T$ The Politics of Negotiating Public Tragedy: Media Framing of the Matthew Shepard Murder', p. 488.

42. See also Dunn, 'Remembering Matthew Shepard: Violence, Identity and Queer Counterpublic Memories', p. 617-21.

43. Ott and Aoki, 'The Politics of Negotiating Public Tragedy: Media Framing of the Matthew Shepard Murder', p. 495.

44. Thernstrom, 'The Crucifixion of Matthew Shepard.' (https://www.vanityfair.com/news/1999/13/matthew-shepard-199903). Cf. Dunn ('The Crucifixion of Matthew Shepard', p. 623-28), who in framing Shepard as a 'secular saint' strangely plays down the clear religious elements of the narratives.

45. Hoffman, 'The Crucifixion of Matthew Shepard', p. 133.

46. Shepard, The Meaning of Matthew: My Son's Murder in Laramie, and a World Transformed, p. 111.

47. Quoted in Shepard, The Meaning of Matthew: My Son's Murder in Laramie, and a World Transformed, p. 134.

48. Shepard, The Meaning of Matthew: My Son's Murder in Laramie, and a World Transformed, p. 162.

49. For the full statement, see Shepard, The Meaning of Matthew: My Son's Murder in Laramie, and a World Transformed, p. 234-47.

50. For the full statement, see Shepard, The Meaning of Matthew: My Son's Murder in Laramie, and a World Transformed, p. 234-47.

51. Shepard, The Meaning of Matthew: My Son's Murder in Laramie, and a World Transformed, p. xiii.

52. Thernstrom, 'The Crucifixion of Matthew Shepard.'

53. Transcribed from Virginia Foxx's speech in the US Senate, 29 April 2009. See: https://www.c-span.org/video/?285575-1/house-session (at 2hr 49min).

54. Segwick, Epistemology of the Closet, p. 18. She later unpacks, where she unpacks her claim that the 'link between extrajudicial and judicial punishment of homosexuality' in the United States is 'endemic'.

55. Charles, 'Panic in the Project: Critical Queer Studies and the Matthew Shepard Murder', p. 246.

56. Dunn, 'Remembering Matthew Shepard: Violence, Identity and Queer Counterpublic Memories', p. 623.

57. For a useful legal history of the gay panic defence, see Bagnall, 
Gallagher, and Goldstein, 'Remembering Matthew Shepard: Violence, Identity and Queer Counterpublic memories', p. 498-515; and Charles, 'Panic in the Project: Critical Queer Studies and the Matthew Shepard Murder', p. 230-36.

58. Charles ('Panic in the Project: Critical Queer Studies and the Matthew Shepard Murder', p. 232-33) argues the logic of the gay panic defence is that there exists a 'public assumption' that 'the expression of same-sex desire is sufficiently anathema to the reasonable juror to warrant violence; and secondly the closet, if disturbed, provokes insanity,' or that a man resorting to violent rage is justifiable on account of 'protecting himself against displays of same-sex affection.'

59. Ibid: 234.

60. See Hoffman, '“Last Night, I Prayed to Matthew”: Matthew Shepard, Homosexuality, and Popular Martyrdom in Contemporary America', p. 147 48.

61. Wypijewski, 'A Boy's Life: For Matthew Shepard's Killers, What Does it Take to Pass as a Man?' p. 71.

62. See especially Walther and Embrick ('White Trash and White Supremacy: An Analysis of the James Byrd Jr. and Matthew Shepard Hate Crimes'); and Dunn ('Remembering Matthew Shepard: Violence, Identity and Queer Counterpublic memories'). Amy Tigner ('Remembering Matthew Shepard: Violence, Identity and Queer Counterpublic memories') uses a different interpretative framework to the same effect, deploying Wild West violent mythology to portray McKinney and Henderson as 'the outlaws'.

63. Wypijewski, 'A Boy's Life: For Matthew Shepard's Killers, What Does it Take to Pass as a Man?' p. 74.

64. See Charles, 'Panic in the Project: Critical Queer Studies and the Matthew Shepard Murder', p. 225-28.

65. Ibid: 231.

66. An epilogue was added to The Laramie Project 10 Years Later to address these counter-narratives.

67. O'Donnell, 'Gay-Hate, Journalism and Compassionate Questioning: Journalism's Response to the Matthew Shepard Case'.

68. See Jensen et al. 'Martyrs for a Just Cause: The Eulogies of Cesar Chavez'p. 628-31.

69. Ott and Aioki, 'The Politics of Negotiating Public Tragedy: Media Framing of the Matthew Shepard Murder', p. 484.

70. Ibid: 486. This is a common theme in critiques of the martyrology, so Wypijewski ('A Boy's Life: For Matthew Shepard's Killers, What Does it Take to Pass as a Man?' p. 74) argues, if 'gay people are recognized only in suffering ... straight people are off the hook.' Similarly, Dunn ('Remembering Matthew Shepard: Violence, Identity and Queer Counterpublic memories' p. 612) critiques the 'heteronormative public remembrance' of Shepard.

71. Walther and Embrick, 'White Trash and White Supremacy: An Analysis of the 
James Byrd Jr. and Matthew Shepard Hate Crimes', p. 250-52; Ott and Aoki, 'The Politics of Negotiating Public Tragedy: Media Framing of the Matthew Shepard Murder', p. 489.

72. Tigner, 'The Laramie Project: Western Pastoral,' p. 139; see also Jensen et al. 'Martyrs for a Just Cause: The Eulogies of Cesar Chavez', p. 631-34.

73. 'The Lesson of Matthew Shepard.' New York Times, 17 October 1998.

74. Loffreda, 'Martyrs for a Just Cause: The Eulogies of Cesar Chavez', p. 19.

75. Quoted in Julie Bindel, 'The Truth Behind America's Most Famous Gay-Hate Murder'. The Guardian, 26 October 1994.

76. Wypijewski, 'A Boy's Life: For Matthew Shepard's Killers, What Does it Take to Pass as a Man?' p. 62.

\section{Works Cited}

Bagnall, Robert; Gallagher, Patrick; Goldstein, Joni. 'Burdens on Gay Litigants and Bias in the Court System: Homosexual Panic, Child Custody, and Anonymous Parties.' Harvard Civil Rights -Civil Liberties Law Review, No. 19, 1994: 497-515.

Besen, Wayne. Anything but Straight: Unmasking the Scandals and Lies behind the Ex-Gay Myth. (London: Routledge, 2003).

Castelli, Elizabeth A. Martyrdom and Memory. Early Christian Culture Making. (New York [etc.]: Columbia University Press, 2004).

Charles, Casey. 'Panic in the Project: Critical Queer Studies and the Matthew Shepard Murder.' Law and Literature, No. 18, 2006: 225-252.

Chapman, Roger, ed. Encyclopedia of the Culture Wars: Issues, Viewpoints, and Voices. (New York: Routledge, 2009).

Cobb, Stephanie L. Divine Deliverance: Pain and Painlessness in Early Christian Martyr Texts. (Oakland: University of California Press, 2017).

Cullen, Dave. 'Who said Yes?' Salon Magazine, 30 September, 1999.

Dreher, Rod. 'Kim Davis: Political Prisoner? Culture-War-Martyr?' The American Conservative. 3 September, 2015.

Dunn Thomas. 'Remembering Matthew Shepard: Violence, Identity and Queer Counterpublic memories.' Rhetoric \& Public Affairs, Vol. 13, No. 4, 2010: 611652

Durham, Martin. The Christian Right, the Far Right and the Boundaries of American Conservatism. (Manchester: Manchester University Press, 2000).

Hoffman, Scott. '“Last Night, I Prayed to Matthew": Matthew Shepard, Homosexuality, and Popular Martyrdom in Contemporary America.' Religion and American Culture: A Journal of Interpretation, Vol. 21, No. 1, 2011: 121-164.

Jensen, Richard; Burkenholder, Thomas; Hammerback, John. 'Martyrs for a Just Cause: The Eulogies of Cesar Chavez.' Western Journal of Communication, Vol. 67, No. 4, 2003: 335-356.

Jimenez, Stephen. The Book of Matt: Hidden Truths about the Murder of Matthew Shepard. (New Hampshire: Steerforth Press, 2013). 
Loffreda, Beth. Losing Matt Shepard: Life and Politics in the Aftermath of an Anti-Gay Murder. (New York: Columbia University Press, 2000).

Middleton, Paul. 'What is Martyrdom?' Mortality: Promoting the Interdisciplinary Study of Death and Dying, Vol. 117, No. 2, 2014: 117-133.

Middleton, Paul. Martyrdom: A Guide for the Perplexed. (London: T \& T Clark, 2011).

Middleton, Paul. Radical Martyrdom and Cosmic Conflict in Early Christianity. LNTS 307. (London: T \& T Clark, 2006).

O’Donnell, Marcus. 'Gay-Hate, Journalism and Compassionate Questioning: Journalism's Response to the Matthew Shepard Case'. Asia Pacific Media Educator, No.19, 2009: 112-125.

Ott, Brian \& Aoki, Erick. 'The Politics of Negotiating Public Tragedy: Media Framing of the Matthew Shepard Murder.' Rhetoric E Public Affairs, No. 5, 2002:483505.

Peyser, Andrea. 'Kim Davis a Martyr for Refusing to Issue Same-Sex Marriage Licenses'. New York Post, 13 September, 2015.

Sedgwick, Eve Kosofsky. Epistemology of the Closet. (Berkeley: University of California Press, 1990).

Shepard, Judy. The Meaning of Matthew: My Son's Murder in Laramie, and a World Transformed. (London: Plume, 2010).

Thernstrom, Melanie. 'The Crucifixion of Matthew Shepard.' Vanity Fair, March, 1999.

Tigner. Amy. 'The Laramie Project: Western Pastoral.' Modern Drama, No. 45, 2002: 138-56

Thorn, Michael. 'Confess the Gay Away? Media, Religion, and the Political Economy of Ex-Gay Therapy.' PhD thesis, York University, Toronto, 2015.

Uberti, David. 'The Media has made Kim Davis a Conservative Martyr, Missing the Bigger Picture.' Columbia Journalism Review, 4 September 2015.

Van Henten, Jan Willem \& Avemarie, Friedrich. Martyrdom and Noble Death: Selected Texts from Graeco-Roman, Jewish and Christian Antiquity. (London: Routledge, 2002).

Walther, C.S. \& Embrick, D.G.T. 'White Trash and White Supremacy: An Analysis of the James Byrd Jr. and Matthew Shepard Hate Crimes.' In Systemic Racism: Making Liberty, Justice, and Democracy Real, eds. Ruth Thompson Miller, Kimberly Ducey (New York: Palgrave Macmillan, 2017), 237-260.

Wilcox, Melissa M. 'Murderers and Martyrs: Violence, Discourse, and the (Re)Construction of Meaning.' Culture and Religion: An Interdisciplinary Journal, No. 2, 2001: 155-178.

Wypijewski, JoAnn. 'A Boy's Life: For Matthew Shepard's Killers, What Does it Take to Pass as a Man?' Harper Magazine, September 1999: 61-74. 